precipitation, evaporation and runoff that might affect the availability of water for irrigation. All of the authors see these changes as potentially serious, but only Bach agrees with a recent assessment by the US Environmental Protection Agency (Can We Delay a Greenhouse Warming?, which was also published last year) that the implications are unequivocally catastrophic.

-What should we do? If we side with all of the authors except Bach, giving weight to the huge uncertainties and the adaptive capabilities of life on Earth, then the wise course is to be alert for signs of nasty consequences (none is yet evident), to take sensible steps to reduce damage to the environment, and to develop a range of alternative options for energy supply and for living in a changing climate. If we share Bach's assessment then a much more active policy is called for. He proposes aggressive energy conservation measures, reforestation, soil conservation and the expeditious development of renewable energy resources. In the short term, the cautious and activist prescriptions may differ little in their practical effect, and by the end of the century, the NAS report proposes, we will know a lot more if we keep up the pace of research. In the meantime, the implementation of elements of Bach's prescription can only be to the good - fear of climate change, like fear of cancer, may lead us into healthier habits that could spare us from many other hazards.

Reading these books leads one to conclude that the $\mathrm{CO}_{2}$ "cottage industry" is serving the public well by clearly illuminating the complexities of this web of scientific and social issues. Others in the business have different strengths. In a popular vein, John Gribbin's Future Weather and the Greenhouse Effect (Delacorte, 1982) has much to recommend it, if its more mystical elements are disregarded. Wilfrid Bach and colleagues have given us two earlier and excellent reviews - Man's Impact on Climate (Elsevier, 1979) and Carbon Dioxide: Current Views and Developments in Energy/Climate Research (Reidel, 1983). Societal aspects were explored by W.W. Kellogg and R. Schware in Climate Change and Society (Westview, 1981), while a detailed scientific analysis was orchestrated by Gordon J. MacDonald (The Long-Term Impacts of Increasing Atmospheric Carbon Dioxide Levels; Ballinger, 1982). A most comprehensive review, edited by William C. Clark, is Carbon Dioxide Review: 1982 (Clarendon, 1982). And the NAS report, Changing Climate, a compendium of reviews, original contributions and synthesis, has already been mentioned.

The books of current vintage contribute much to this literature, and all can be recommended. Both Jäger and Bach are distinctive and important additions. Jăger's comprehensive view of climate through the prism of energy is unique and illuminating. Bach, though regrettably impeded by abominable computer typesetting, presents an impressively scholarly and exhaustive treatment. While his road leads to but one conclusion, it is broad and solidly built.

The next few years will bring further contributions. The US Department of Energy will soon release an assessment of the knowledge and conclusions emanating from its massive research programme, and an international effort is laying the groundwork for a 1985 intergovernmental conference. Thus, as was observed in the NAS report, while $\mathrm{CO}_{2}$ may be a worrisome issue, it may also be a healthy stimulus which forces us to address seriously the long-term maintenance of our planetary home.

John S. Perry is Staff Director of the Board on Atmospheric Sciences and Climate of the US National Academy of Sciences.

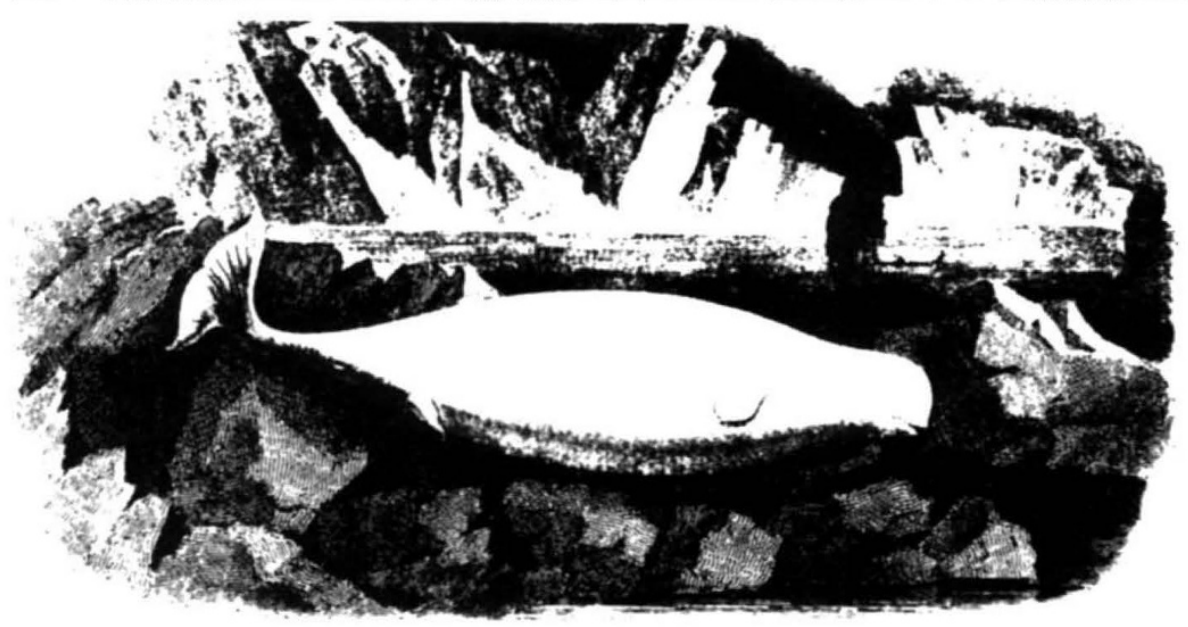

\footnotetext{
"Beluga or White Whale", from William Scoresby's An Account of the Arctic Regions, with a History and Description of the Northern Whale-Fishery, (1820). The illustration is reproduced from Voyage into Substance: Art, Science, Nature, and the Illustrated Travel Account, 1760-1840, by Barbara Maria Stafford, recently published by MIT Press. Price is $\$ 39.95, £ 41.75$.
}

\section{Cells: bags of water or blobs of jelly?}

\author{
D.A.T. Dick
}

In Search of the Physical Basis of Life. By Gilbert N. Ling.

Plenum: 1984. Pp. 791. \$79.50, £67.57.

QUANTITATIVE membrane theories, such as those of Boyle and Conway and the Hodgkin-Katz-Goldman equation, achieved spectacular success in the 1940s. These, along with Hodgkin and Keynes's demonstration of rapid potassium diffusion in the squid axon, induced a widespread view among physiologists that the cell is simply a membrane-bounded bag. In it, so the story ran, is a fairly homogeneous, aqueous soup of proteins and inorganic ions, the composition and electrical potential of which is controlled by the membrane. By contrast, a heterodox group of physiologists - led in particular by Troschin in Russia and by Ling in the United States - has maintained that the cell is essentially a blob of jelly, held together by controlled intermolecular forces between protein molecules to which water and the ionic constituents are variably bound. This view, called by Ling the association-induction theory, has been pursued to the extent of denying any significant role to the cell membrane.

Neither of these extreme stances is of course correct. In addition to the ample evidence for the function of the cell membrane, it is now known that the cellular matrix possesses a structure of microtubules and microfilaments (see for example J. Cell Biol. 99, No. 1, Pt 2; 1984), that in some cells the distribution of ions (particularly sodium and potassium) is not uniform within the cell, and that at least some cellular water is bound. Thus there is sore need of an impartial review of alternative theories of the cell.

Dr Ling's book is divided into five sections, the first of which surveys concepts in cell physiology in a historical framework (here the most important chapter is the fifth which deals with the evidence for and against the membrane theory of the cell). The second section gives a full account of Ling's associationinduction theory, particularly in relation to the control of the sodium, potassium and water contents of the cell. The third is largely devoted to the experimental work of Ling and his colleagues in support of the association-induction theory, while the fourth gives an account of mitochondria, muscle and epithelial transport, usually rejecting conventional physiological views and reinterpreting the data in terms of the association-induction hypothesis. The final section describes recent work on protein synthesis, growth and differentiation, and cancer, and offers speculative interpretations of these phenomena again 